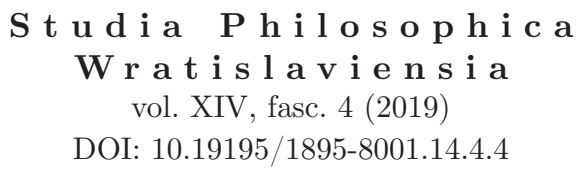

Ks. MAREK SOETYSIAK

ORCID: 0000-0003-4437-0321

UPJP II w Krakowie

\title{
Założenia ontologiczne i epistemologiczne sceptycyzmu Montaigne'a
}

\section{The Ontological and Epistemological Assumptions of Montaigne's Scepticism}

\begin{abstract}
Montaigne is widely regarded as one of the most significant sceptics of the 16th century. His most important work, Essays, had a great impact on the thinkers of the 16th and 17th centuries, in particular on the philosophy of Descartes. The article presents Montaigne's critique of senses and reason as sources of human knowledge. The elements of his scepticism that went beyond the sceptic arguments of ancient thinkers has been emphasized. The negative role of his ontological variabilism in knowing things has been underlined. As a result of the total criticism of the possibilities of human cognition made by the author of the Essays, attention has been paid to the non-sceptical type of the question posed by him: "What do I know?" ("Que sais-je?"). The answer to this question led him to fideism in cognition. At the end of the article, an attempt has been made to indicate Montaigne's main epistemological and metaphysical assumptions that contributed to the problem of cognition. It has also been highlighted in what way the understanding of reason, method, and, above all, self became for Descartes, unlike Montaigne, the foundation of certain knowledge.
\end{abstract}

Keywords: Montaigne, scepticism, fideism, truth

Studia Philosophica Wratislaviensia 14, z. 4, 2019

(C) for this edition by CNS 
Michel de Montaigne (1533-1592) uważany jest za założyciela nowożytnego sceptycyzmu i jednego z najbardziej wpływowych myślicieli w jego rozwoju ${ }^{1}$. W swoim głównym dziele zatytułowanym Próby $y^{2}$ przedstawia argumenty przeciw możliwościom poznania, zarówno starożytnych sceptyków, jak i własne. Najważniejszymi źródłami jego wiedzy o starożytnym sceptycyzmie były: Księgi akademickie Cycerona, Żywoty i poglady sławnych filozofów Diogenesa Laertiosa, a przede wszystkim Zarysy pirrońskie Sekstusa Empiryka ${ }^{3}$. Prace te były praktycznie nieznane w całym łacińskim średniowieczu, ale gdy odzyskano je w okresie renesansu, w znacznym stopniu przyczyniły się do kryzysu pirrońskiego ${ }^{4}$. Montaigne po przeczytaniu w 1576 roku Zarysów pirrońskich przeszedł ,kryzys sceptyczny"5, którego dobitnym wyrazem jest najważniejszy, a zarazem najdłuższy esej zatytułowany Apologia Rajmunda Sebond. W Apologii Montaigne nie tylko ukazuje argumenty starożytnych sceptyków, ale przede wszystkim własne stanowisko filozoficzne. O znaczeniu, popularności i wpływie Prób Montaigne'a na ówczesnych myślicieli niech świadczy opinia Étiennego Gilsona, że „filozofia Kartezjusza była rozpaczliwym wysiłkiem wydobycia się ze sceptycyzmu Montaigne'a" ${ }^{\prime 6}$.

Użycie przez Montaigne'a formy eseju w pisaniu Prób pozwoliło mu zestawić alternatywne perspektywy w zakresie tematów, które poruszał. Ale forma ta

${ }^{1}$ Por. M.B. Vázquez, The Skepticism of Michel de Montaigne, New York 2015, s. IX; A. Hartle, Montaigne and skepticism, [w:] U. Langer, The Cambridge Companion to Montaigne, New York 2005, s. $183-206$.

${ }^{2}$ Montaigne rozpoczął pisać swoje eseje po rezygnacji z działalności publicznej w roku 1571, w sławnej wieży rodowego zamku. Pierwszy zbiór esejów został przez niego wydany w dwóch księgach pod tytułem Essais w 1580 roku. Kolejne eseje pisał aż do swojej śmierci.

${ }^{3}$ Jednym z najważniejszych wydarzeń w historii nowożytnego sceptycyzmu było ponowne odnalezienie i opublikowanie w 1562 roku łacińskiego tłumaczenia fragmentów pism Sekstusa Empiryka autorstwa Henri Estienne'a oraz kompletnego łacińskiego wydania jego pism przez Gentiana Herveta w roku 1569. Por. R.H. Popkin, The History of Scepticism from Erasmus to Spinoza, Berkeley 1979, s.19.

${ }^{4}$ Według R.H. Popkina kryzys w myśleniu pojawił się pod koniec XVI i na początku XVII wieku jako kryzys pirroński. Całą wiedzę podano w wątpliwość. Kryzys ten był w dużej mierze spowodowany publikacja pism Sekstusa Empiryka. Por. R.H. Popkin, The Sceptical Crisis and the Rise of Modern Philosophy, „The Review of Metaphysics”, 7 (1953), s. 132-151. Na temat kryzysu pirrońskiego zob. A. Hartle, op. cit., s. 184 n.; R. Ziemińska, Historia sceptycyzmu. W poszukiwaniu spójności, Toruń 2013, s. 202-203.

${ }^{5}$ Motto z Zarysów pirrońskich Sekstusa „Que sais-je?” („Co ja wiem?”) miał wyryte na belce krokwi swego gabinetu i przyjął je jako własne. Por. R.H. Popkin, Montaigne, Michel Eyquem de (1533-1592), [w:] D.M. Borchert, Encyclopedia of Philosophie, t. 6, Detroit-New York 2005, s. 287-290.

${ }^{6}$ É. Gilson, Jedność doświadczenia filozoficznego, tłum. Z. Wrzeszcz, Warszawa 2001, s. 91. Wiele argumentów podważających zmysły jako podstawę wiedzy użytych przez Montaigne'a w jego głównym dziele Próbach pojawiło się pośrednio lub bezpośrednio w Medytacjach o pierwszej filozofii Kartezjusza. Por. A. Hartle, op. cit., s. 189. R. Ziemińska zwraca uwagę, że „Destrukcja rozumu ludzkiego dokonana przez Montaigne'a zmusza Descartes'a, aby zaczął swoje filozofowanie od rozprawy ze sceptycyzmem" (R. Ziemińska, Michel de Montaigne jako sceptyk renesansowy, [w:] Z dziejów filozoficznej refleksji nad człowiekiem. Ksiega Pamiatkowa ku czci Profesora Jana Czerkawskiego (1939-2007), P. Gutowski, P. Gut (red.), Lublin 2007, s. 211). O bardzo dobrej znajomości myśli sceptycznej Montaigne'a przez Kartezjusza świadczy lista fragmentów z Rozprawy o metodzie, będących jedynie echem Prób. Gilson w swoim komentarzu do Rozprawy o metodzie przedstawia dwadzieścia dziewięć takich odniesień. Por. R. Descartes, Discours de la Méthode. Texte et Commentaire par Étienne Gilson, Paris 1987. 
przyczyniła się także do różnorodnych interpretacji jego sceptycyzmu. Według Richarda Popkina Montaigne jest kontynuatorem pirrońskiego sceptycyzmu ${ }^{7}$. Manuel B. Vázquez nie podziela tego stanowiska i jest przekonany, że Montaigne bardziej był skłonny do wątpliwości akademickich niż do pirrońskich ${ }^{8}$. Natomiast Frédéric Brahami uważa, że autor Prób ostatecznie porzucił sceptycyzm i dlatego należy uważać go za antyracjonalistę . W podobnym tonie co Brahami pisze Ann Hartle, zwracając uwagę na wątki antysceptyczne występujące w twórczości Montaigne'a ${ }^{10}$. Z kolei Renata Ziemińska uważa, że

sceptycyzm Montaigne'a jest umiarkowany i można go sprowadzić do postawy nieustannego poszukiwania prawdy, postulatu ostrożności w sądzeniu czy fallibilizmu (człowiek nie dysponuje wiedzą praktyczną) [...]. Są jednak takie fragmenty Apologii, które przemawiają za interpretacją Montaigne’a jako totalnego sceptyka ${ }^{11}$.

Michel de Montaigne był tym filozofem, któremu przypadło żyć w czasie sceptycznego kryzysu we Francji w drugiej połowie XVI wieku. Kryzys ten związany był z wystąpieniem Lutra, wojnami religijnymi we Francji, z odkryciem Nowego Świata oraz z udostępnieniem dzieł starożytnych sceptyków szerokiej rzeszy czytelników. Dla nas istotne są wątpliwości dotyczące możliwości osiągnięcia przez człowieka pewnej wiedzy niezależnie od Bożego objawienia. W artykule spróbuję przedstawić najpierw te argumenty sceptyczne Montaigne'a, które dotyczą jego krytyki poznania zmysłowego i rozumowego, następnie przedstawię przyjętą przez niego koncepcję bytu, która uniemożliwiła mu poznanie świata zarówno zewnętrznego, jak i wewnętrznego. W kolejnym etapie naszych analiz za autorem Prób spróbuję odpowiedzieć na pytanie: co właściwie wiemy po podważeniu możliwości poznania zmysłowego i rozumowego? Przeanalizuję także odpowiedź Montaigne'a, że jedyną możliwością poznania prawdy jest zaufanie Bożej opatrzności, czyli przyjęcie fideizmu. Na zakończenie spróbuję krytycznie ustosunkować się do przyjętych założeń Montaigne'a i odpowiedzieć na pytanie, dlaczego przyjęte przez niego założenia uniemożliwiają poznanie świata i drugiego człowieka.

\section{Krytyka poznania zmysłowo-intelektualnego}

Poglądy sceptyczne Montaigne'a zawarte w Próbach są wyrazem jego doświadczenia życiowego, odzwierciedleniem jego sceptycyzmu praktycznego. Na co dzień stykał się z izostenią sądów dotyczących religii, obowiązujących praw oraz poglądów społeczno-politycznych. Z różnorodnością poglądów religijnych zetknął się we własnej rodzinie. Jego ojciec Pierre Eyqem Montaigne brał udział w wojnach włoskich (1494-1559) jako katolicki żołnierz. Jego matka Antoinette Lopez de Villanueva, z pochodzenia żydówka, przeszła z katolicyzmu na protestantyzm. Dziadek od strony matki pochodził z bogatej hiszpańsko-portugalskiej rodziny żydowskiej,

\footnotetext{
${ }^{7}$ Por. R.H. Popkin, The History of Scepticism from Erasmus to Descartes...

${ }^{8}$ Por. M.B. Vázquez, op. cit.

${ }^{9}$ Por. Fr. Brahami, Le scepticisme de Montaigne, Paris 1997, s. 106-107.

${ }^{10}$ Por. A. Hartle, op. cit., s. 183-206.

11 R. Ziemińska, Historia sceptycyzmu..., s. 211.
} 
która przeszła na katolicyzm. Brat i siostra Michela zostali protestantami ${ }^{12}$. Całe jego dorosłe życie przypadło na okres wojen religijnych we Francji między katolikami a protestantami. W latach 1562-1598 miało miejsce osiem odrębnych wojen domowych, zakończonych ostatecznie edyktem nantejskim w $1598 \mathrm{roku}^{13}$. Montaigne nie tylko był świadkiem tych wojen, lecz brał w nich czynny udział, często jako negocjator między zwaśnionymi stronami.

Konflikty między protestantami a katolikami wywołały również ogólnoeuropejski kryzys prawny i konstytucyjny ${ }^{14}$. Był to czas narodzin nowoczesnych państw. Pojawienie się międzynarodowego ruchu reformatorskiego przyczyniło się do rozwoju teorii zbrojnego oporu wobec państwa. W luterańskich Niemczech reformacja protestancka doprowadziła do redefinicji świeckiego i urzędniczego autorytetu i przerobienia tradycyjnego niemieckiego prawa na wzór dawnego rzymskiego prawa cywilnego ${ }^{15}$. W Kościele katolickim kontrreformacja spowodowała pojawienie się nowego konstytucjonalizmu. Wszystko to przyczyniło się do zamieszania i chaosu w rozumieniu państwa i prawa. Michel, będąc z wykształcenia prawnikiem, sam doświadczył tej zmienności prawa ${ }^{16}$. Przekonał się, że metody stosowane w polityce nie mają nic wspólnego z moralnością ${ }^{17}$.

Potwierdzeniem jego przeświadczenia o względności wszelkich praw i obyczajów miały być wydarzenia rozgrywające się w Anglii w czasie, kiedy pisał Próby.

Nie ma nic bardziej podległego ustawnym wstrząśnieniom, niż prawa. Od początku mego życia widziałem, jak Anglicy, nasi sąsiedzi, odmieniali je trzy lub cztery razy, nie tylko w materii politycznej, która powszechny sąd zwalnia z obowiązku stałości, ale w najważniejszym przedmiocie, jaki być może, to jest religii ${ }^{18}$.

Anglia za rządów Henryka VIII przeszła z katolicyzmu na anglikanizm (od 1534 roku), za panowania jego córki Marii Tudor przywrócono katolicyzm (1553-1558), a kiedy tron królewski objęła Elżbieta I (1558-1603), ponownie wprowadziła anglikanizm.

W 1562 roku Montaigne wraz z armią królewską wziął udział w wyprawie przeciwko miastu Rouen, które było jednym z głównych ośrodków hugenotów we Fran-

12 Por. G. Paganini, Michel de Montaigne, [w:] Skepticism: from antiquity to the present, D.E. Machuca, B. Reed (eds.), New York 2018, s. 232. Zob. R.H. Popkin, The History of Scepticism from Erasmus to Descartes..., s. 44.

${ }^{13}$ Por. B. Chevalier, France from Charles VII to Henry IV, [w:] Handbook of European History 1400-1600, T.A. Brady, H.A. Oberman, J.D. Tracy (red.), t. 1, Leiden-New York-Köln 1994, s. 369-401.

${ }^{14}$ Por. Q. Skinner, The Foundations of Modern Political Thought. The Age of Reformation, t. 2, Cambridge 1978.

15 Por. M.B. Vázquez, op. cit., s. 110.

${ }^{16}$ Praktykę sądowniczą rozpoczął w Périgueux, a następnie pracował jako radca królewski w Bordeaux. Por. M. Ciszewski, Montaigne, [w:] Powszechna Encyklopedia Filozofii, St. Wielgus (red.), t. 7, Lublin 2006, s. 372. Także jako burmistrz Bordeaux (1581-1585) miał okazję uczestniczyć i doświadczać zmienności praw w czasach politycznego niepokoju.

${ }^{17}$ Por. Por. M. de Montaigne, O użytecznym i o uczciwym, [w:] idem, Próby, t. 3, tłum. T. Boy-Żeleński, Warszawa 1985, s. 41-54.

${ }^{18}$ M. de Montaigne, Apologia Rajmunda Sebond, [w:] idem, Próby, t. 2..., s. 256. 
cji. Tam też spotkał Indian przywiezionych z Ameryki Południowej ${ }^{19}$. To spotkanie zaowocowało jego badaniami kultur pozaeuropejskich i w efekcie pogłębiło jego sceptyczne poglądy dotyczące obyczajowości.

Zdobyte doświadczenie wraz z lekturą starożytnych sceptyków utwierdziło go w przekonaniu o niemożności poznania świata zewnętrznego. Montaigne nie tylko przejął ich sceptyczne argumenty, ale znacząco je zmodyfikował. Nie troszczył się zbytnio o to, czy jego nowe argumenty przeciw możliwości poznania mieszczą się jeszcze w granicach sceptycyzmu starożytnego ${ }^{20}$. Główny argument przejęty przez niego z Zarysów pirrońskich wiązał się z izostenią sądów. To, czego doświadczał w swojej działalności publicznej, teraz miało się doczekać opracowania teoretycznego. Zgodnie z twierdzeniem Protagorasa człowiek nie ma obiektywnego kryterium oceny wydawanych przez siebie twierdzeń. O tym samym przedmiocie sporu można sformułować dwa sądy wzajemnie się wykluczające, a nie majacc kryterium ich oceny, nie można orzec, który z nich jest prawdziwy. Dlatego należy zachować ostrożność w wygłaszaniu jakichkolwiek pewnych twierdzeń. Pytanie o kryterium wiedzy stało się dla Montaigne'a osnową jego krytyki poznania zmysłowego i rozumowego oraz spowodowało przyjęcie przez niego metafizycznego założenia dotyczącego zmienności rzeczy.

Montaigne krytykuje, podobnie jak sceptycy starożytni, zdroworozsądkową koncepcję poznania, mającą swe korzenie w filozofii Arystotelesa. W związku z tym pisze w Apologii, że rzekomo prawdziwe ,poznanie dochodzi do nas przez zmysły [...]. Wiedza zaczyna się od nich i w nich się zamyka [...]. Zmysły są początkiem i końcem ludzkiego poznania"21. Według tej teorii umysł jest czystą tablica (tabula rasa $)^{22}$, a cały materiał poznania pochodzi z doświadczenia zmysłowego. Arystoteles uważał, że każdy człowiek postawiony w „normalnej” sytuacji, ze zmysłami i rozumem dobrze dostrojonymi do natury, jest w stanie uzyskać adekwatną i prawdziwą reprezentację rzeczywistości zewnętrznej. W procesie poznania rzeczy znajdującej się poza świadomością występuje podwójne zapośredniczenie, najpierw między rzeczą a jej zmysłowym ujęciem, następnie między jej zmysłowym ujęciem a intelektem. Intelekt poznaje rzecz tylko za pośrednictwem jej zmysłowego ujęcia. Proces poznawczy rozpoczyna się od uchwycenia przez zmysły formy poznawczej rzeczy (species sensibilis). Zmysłowa forma poznawcza przekazywana jest przez zmysły do zmysłu wspólnego (rozumu biernego). Rozum czynny w procesie abstrakcji wydobywa z jednostkowej, zmysłowej formy poznawczej intelektualną formę poznawczą (species intelligibilis), czyli istotę rzeczy, i przekazuje

${ }^{19}$ W wyniku odkryć geograficznych w XV i XVI wieku następuje zetknięcie się ludności basenu Morza Śródziemnomorskiego z odmiennymi cywilizacjami, ich tradycjami i obyczajowością. Przy pomocy tłumacza Montaigne przeprowadził wywiad z jednym z rdzennych mieszkańców Ameryki Południowej i umieścił go potem w Próbach w rozdziale $O$ kanibalach. Po tej wyprawie jeszcze dwukrotnie brał udział w wojnie.

${ }^{20}$ Hartle analizuje antysceptyczne argumenty Montaigne'a. Por. A. Hartle, op. cit.

${ }^{21}$ M. de Montaigne, Apologia..., s. 264. Montaigne, głosząc, że cała wiedza pochodzi od zmysłów, partycypuje w formule empiryzmu genetycznego Locka.

${ }^{22}$ Por. Arystoteles, O duszy, tłum. P. Siwek, [w:] idem, Dzieła wszystkie, t. 3, tłum. P. Siwek, Warszawa 1992, s. 125. 
ją do rozumu potencjalnego. Ujęcie form poznawczych (species) najpierw przez zmysły, następnie przez rozum czynny gwarantuje wiarygodny pomost między reprezentacją a tym, co jest reprezentowane, czyli między zmysłowym ujęciem rzeczy a samą rzeczą, następnie między zmysłowym ujęciem rzeczy a jej pojęciem. To przedstawienie zdroworozsądkowego procesu poznawczego ma istotne znaczenie dla naszych rozważań. Zakwestionowanie przez Montaigne'a świadectwa zmysłów w poznaniu powoduje równocześnie zanegowanie ważności rozumu, ponieważ ma on dostęp do świata zewnętrznego tylko za pośrednictwem zmysłów.

Montaigne w Próbach odrzuca nie tylko całą aparaturę pojęciową scholastyki, związaną z materią i formą oraz formami poznawczymi (species), lecz takżė̇ Arystotelesowską psychologię, która stanowiła fundament realistycznej koncepcji poznania. Aby uwydatnić nieadekwatność między przedmiotem a jego zmysłową reprezentacją, wskrzesza rozróżnienie pirrońskie między zjawiskiem a przedmiotem ${ }^{23}$ :

Nasza świadomość nie ma innej styczności z zewnętrznymi zjawiskami, jeno rodzi się za pośrednictwem zmysłów; zmysły zasię nie ogarniają zewnętrznego przedmiotu, jeno własne uczucia: świadomość tedy i pojęcie nie pochodzą z danego przedmiotu, jeno z odczucia i wrażenia zmysłów. Owóż odczucie przedmiotu a sam przedmiot to są rzeczy różne: dlatego, kto sądzi z wrażeń, sądzi z czego innego niż z przedmiotu ${ }^{24}$.

Montaigne, aby wykazać, że wrażenie przedmiotu, które jest uchwycone przez naszą świadomość, nie jest adekwatne do przedmiotu istniejącego niezależnie od niej, musi podważyć wiarygodność zmysłów. Dla udowodnienia „braku pomostu” między wrażeniem a przedmiotem poznania Montaigne w Apologii podąża za słynnymi dziesięcioma trybami Ainezydema, przedstawionymi w Zarysach pirrońskich. Cała nasza rzekoma wiedza, argumentował, wydaje się pochodzić z doświadczenia zmysłowego, ale być może nie mamy wystarczającej liczby zmysłów do jej zdobycia:

powątpiewam, aby człowiek obdarzony był wszystkimi istniejącymi naturalnymi zmysłami. Widzę rozmaite zwierzęta, które żyją pełnym i doskonałym życiem, jedne bez wzroku, drugie bez słuchu: kto wie, czy i nam także nie brakuje jeszcze jednego, dwu, trzech i wiele więcej zmysłów?25

Nawet jeśli mamy wszystkie zmysły, to informacje, które zdobywamy za ich pośrednictwem, są zwodnicze i niepewne.

Nie posiadamy odpowiedniego kryterium, które upewniałoby nas, że to, co przedstawia nam dany zmysł, odpowiada faktycznemu stanowi rzeczy reprezentowanemu przez wrażenie zmysłowe: „Kto nie znał Sokratesa, ten, widząc jego portret, nie może powiedzieć, że jest doń podobny"26. Oprócz tego, że świadectwo jednego zmysłu nie jest weryfikowane ani nie jest uzupełniane przez świadectwo in-

${ }^{23}$ W rzeczywistości Montaigne nigdy nie użył terminu ,zjawisko”, które było wówczas postrzegane jako greckie słowo i nie było akceptowane jako łaciński lub francuski termin do czasów Kartezjusza i Leibniza (ten ostatni był pierwszym, który obszernie użył tego słowa zarówno w swoich łacińskich, jak i francuskich pismach). Chociaż w Próbach nie pojawił się sam termin, to jednak jest obecne jego znaczenie. Por. G. Paganini, op. cit., s. 237.

${ }^{24}$ Ibidem, s. 276.

${ }^{25}$ M. de Montaigne, Apologia..., s. 264-265.

${ }^{26}$ Ibidem, s. 276. 
nych zmysłów ${ }^{27}$, to dodatkowo wrażenia naszych zmysłów kolidują z sobą, na przykład wzrok i dotyk dają sprzeczne wrażenia tego samego przedmiotu. Także w tym przypadku nie istnieje ,żaden sędzia" (żadne kryterium) rozstrzygajacy spory między wrażeniami zmysłowymi, ponieważ

[a]by ocenić wrażenia, jakie odbieramy od przedmiotów, trzeba by nam instrumentów do ich sprawdzenia; aby znów sprawdzić ten instrument, trzeba doświadczenia; aby sprawdzić doświadczenie — instrumentu: i oto wpadamy w błędne koło ${ }^{28}$.

Wydaje się, że pomocą w rozstrzygnięciu problemu błędnego koła związanego ze świadectwem zmysłów może być rozum. Jednakże w odniesieniu zarówno do rozumu, jak i wcześniej do zmysłów pojawia się pytanie o kryterium prawdziwości jego poznania. Skąd mamy mieć pewność, że nasz rozum w poznaniu tego, co dostarczają mu zmysły, nie popełnia błędów: ,żaden rozum nie może być uznany za pewny bez drugiego rozumu: i oto cofamy się wstecz aż do nieskończoności"29.

Iluzje występujące w poznaniu prowadzą nas do zastanawiania się, „czy nasze myślenie, nasze działanie, nie jest rodzajem mary sennej, a nasze czuwanie jakowymś rodzajem snu"30. Jeżeli przyjmiemy za Montaigne'em, że poznajemy nasze wrażenia, a nie rzeczy, to odróżnienie wrażeń, które mamy podczas snu od wrażeń, których doświadczamy na jawie, wydaje się niemożliwe. Również każde nasze nowe doświadczenie różni się od wcześniejszych doświadczeń, jest odmienne od doświadczeń zwierząt oraz od przeżyć innych ludzi. Jeżeli nie posiadamy odpowiedniego kryterium, nie możemy wiedzieć, które z nich jest właściwe.

Montaigne, podsumowując przytoczone przez siebie argumenty starożytnych sceptyków, pyta retorycznie:

skoro wpływ choroby, przewidzenia lub snu ukazuje nam rzeczy w innej postaci, niż się wydają zdrowym, rozsądnym i będącym na jawie, czyż nie jest prawdopodobne, iż nasz zwyczajny stan i przyrodzone humory również mają władzę użyczać rzeczom bytu wedle siebie samych i dostrajać je do siebie, tak jak to czynią humory nieprawidłowe? ${ }^{31}$

A zatem to struktura podmiotu poznającego stanowi źródło niepewności sądów o rzeczywistości. Wręcz rewolucyjny jest jego wniosek dotyczący warunków możliwości poznania przedmiotu:

skoro nasz stan przystosowuje rzeczy do siebie i przekształca je wedle siebie, tracimy zgoła sąd o tym, jakimi są rzeczy w istocie; wszystko bowiem dochodzi do nas jeno sfałszowane i odmienione przez zmysły [...]. Niepewność zmysłów czyni niepewnym wszystko, co one nam przywodzą32.

${ }^{27}$ Por. ibidem, s. 265. Montaigne, podkreślając niedoskonałość poznania zmysłowego, zwraca uwagę na potrzebę porozumiewania się w poznaniu nie tylko między ludźmi, lecz także na branie pod uwagę poznania zwierząt, ponieważ ich zmysły są doskonalsze od naszych. Por. ibidem, s. 274.

${ }^{28}$ Ibidem, s. 276.

29 Ibidem.

${ }^{30}$ Ibidem 272, por. ibidem, s. 246. Przypisywany Kartezjuszowi argument, że nie można odróżnić snu od jawy, prawdopodobnie został przez niego przejęty od Montaigne'a. I. Dąmbska twierdzi, że zaczerpnął go od starożytnych autorów. Występuje on już u Heraklita, u Platona w Teajtecie, a także u Karneadesa i u św. Augustyna. Por. I. Dąmbska, Zagadnienia marzeń sennych w greckiej filozofii starożytnej, [w:] eadem, Znaki i myśli, Warszawa 1975, s. 138.

31 Ibidem, s. 275.

32 Ibidem. 
Montaigne, twierdząc, że to „nasz stan przystosowuje rzeczy do siebie”, na dwa wieki przed Immanuelem Kantem wskazuje na czynną rolę naszych władz poznawczych w konstytuowaniu poznawanej rzeczy. Zapowiada w ten sposób transcendentalny zwrot w filozofii. Jednak jego wniosek dotyczacy udziału podmiotu w procesie poznania jest całkowicie sceptyczny. Podmiot, przekształcając przedmiot poznania i dostosowując go do siebie, fałszuje go. Na pytanie, co było powodem takiego stanowiska Montaigne’a, spróbuję odpowiedzieć w dalszej części artykułu.

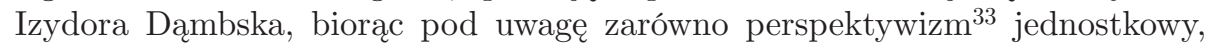
jak i gatunkowy w koncepcji poznania Montaigne’a, stwierdza, że:

Człowiek stoi zagubiony we wszechświecie, słaby i niedołężny wobec ogromu otaczających i przytłaczających go tajemnic. Nie wiemy, jakie są pierwsze zasady bytu i co gorsza, nie znamy sposobów ich poznania. Ale nie mamy też rozumnego powodu, by odrzucić to wszystko, czego bezpośrednio zmysłami ująć nie można ${ }^{34}$.

W konsekwencji dla pirronisty takiego jak Montaigne, przynajmniej tak jest w Apologii Rajmunda Sebond, wrażenia i jakiekolwiek reprezentacje mentalne nie gwarantuja ani epistemologicznie, ani ontologicznie poznania przedmiotu.

Jeżeli świadectwo zmysłów jest niewiarygodne w poznaniu rzeczy, to również rozum jest bezużyteczny w jej ujęciu, ponieważ tylko za pośrednictwem zmysłów ma on kontakt ze światem zewnętrznym. Zdaniem Montaigne'a większość ludzi pomija tę prawdę i przyjmuje fałszywe założenie, że to dzięki rozumowi człowiek

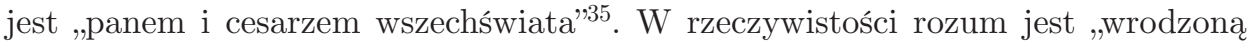
i pierwotną chorobą"36, która fałszuje poznawaną przez nas rzeczywistość. Na dowód głoszonego przez siebie poglądu prezentuje listę ponad dwudziestu siedmiu różnych, często sprzecznych z sobą teorii dotyczących natury Boga ${ }^{37}$. Uzupełnia ja krytyką filozoficznych poglądów na temat natury ludzkiego ciała i duszy. Poznanie rozumowe nie umożliwia człowiekowi poznania prawdy.

Z dezaprobatą odnosi się do ludzi, którzy z „bezwstydną” pychą postępują ze zwierzętami jako z istotami niższego rzędu ${ }^{38}$. Według jego obserwacji nic nie uprawnia człowieka do takiej postawy, ponieważ zwierzęta podobnie jak ludzie maja inteligencję ${ }^{39}$. Wraz ze zwierzętami należymy do natury, która jest naszym właści-

${ }^{33}$ Por. D. Leszczyński, Między watpieniem a wiara. Próba charakterystyki renesansowego sceptycyzmu, ,Studia Philosopica Wratislaviensis” 1 (2006), s. 119-120.

${ }^{34}$ I. Dąmbska, Sceptycyzm francuski XVI i XVII wieku, Toruń 1958, s. 26.

35 Por. M. de Montaigne, Apologia..., s. 138.

${ }^{36}$ Por. ibidem, s. 140.

37 Por. ibidem, s. 196 n.

${ }^{38}$ Por. ibidem, s. 140. Montaigne, według Pascala, przeczy sam sobie, twierdząc, że ludzie w niczym nie przewyższają zwierząt. Sprzeczność jego postawy polega na tym, że wypowiadając to twierdzenie, z jednej strony gardzi ludźmi, a z drugiej, sam będąc człowiekiem, jest w stanie je wypowiadać, tzn. że sytuuje się wyżej niż świat zwierzęcy: „A ci, którzy najbardziej gardzą ludźmi i równają ich z bydlętami, i ci chcą, aby ich podziwiano i wierzono im, i przeczą sami sobie tym uczuciem, ile że natura ich, mocniejsza nad wszystko, silniej przekonywa ich o wielkości człowieka niż rozum o jego nikczemności" (B. Pascal, Myśli, tłum. T. Boy-Żeleński, Warszawa 1983, nr 276, s. 110).

${ }^{39}$ Por. M. de Montaigne, Apologia..., s. 141. Szerzej na temat relacji człowieka do świata zwierząt pisze M. Wild, Die anthropologische Differenz. Der Geist der Tiere in der frühen Neuzeit bei Montaigne, Decartes und Hume, Berlin-New York 2006. 
wym środowiskiem. Jednak ze względu na rozum człowiek odrzucił tę wspólnotę, a przez to skazał siebie „na niewiedzę, zewsząd otacza go nieprzenikniona tajemnica wszechświata, rozum ludzki jest ślepy i niezdolny odróżnić prawdę od fałszu"40.

Krytyka rozumu dokonana przez Montaigne'a dotyczy także eudajmonologii Arystotelesa. Według autora Prób proponowana przez Stagiryty wiedza jest bezwartościowa w poszukiwaniu szczęścia ${ }^{41}$, ponieważ to nie rozum, lecz ignorancja i prostota umożliwiają człowiekowi osiągnąć spokój duszy i w konsekwencji szczęście ${ }^{42}$.

\section{Niemożność określenia tożsamości rzeczy}

Seria przytoczonych przez Montaigne'a argumentów podważających wiarygodność zmysłów oraz rozumu jako fundamentów ludzkiej wiedzy kulminuje się w metafizycznym twierdzeniu, że wszystkie rzeczy, zarówno my sami, jaki i przedmioty przez nas poznawane, ciągle się zmieniają:

nie ma żadnego stałego istnienia ani w naszej istocie, ani w innych przedmiotach; i my, i nasz sąd, i wszystkie rzeczy śmiertelne toczą się i płyną bez ustanku. Nie da się tedy nic ustalić pewnego z jednego o drugim, gdyż i sądzący podmiot, i sądzone przedmioty znajdują się w nieustannej odmianie i ruchu. [Dlatego — M.S.] [n]ie mamy żadnego porozumienia z bytem [... $]^{43}$.

Montaigne w odróżnieniu od sceptyków starożytnych przyjmuje coś pozytywnego, mianowicie twierdzi, że istotą rzeczy jest ich zmienność. Zmienność określa istotę zarówno człowieka, jak i poznawanych rzeczy. Autor Prób metaforycznie porównuje byt świata i istniejących w nim rzeczy do huśtawki:

Świat jest wiekuistą huśtawką; wszystkie rzeczy huśtają się na niej bez przerwy, ziemia, skały Kaukazu, piramidy Egiptu; tak powszechnym, jak i swoim własnym ruchem. Stałość nawet nie jest niczym innym, jak bardzo powszechnym chwianiem $^{44}$.

Swoje rozważania dotyczące istoty bytu łączy z przyjętą przez siebie koncepcją czasu:

Czas jest to rzecz ruchoma, która objawia się jak cień, płynąc i tocząc się wraz z materią ustawicznie, nigdy nie zostając w stałości i spoczynku. On to zawiera w sobie te słowa Wprzód i Potem,

40 Z. Gierczyński, Wstęp, [w:] M. de Montaigne, Próby, tłum. T. Boy-Żeleński, Warszawa 1985, s. 22.

${ }^{41}$ Por. M. de Montaigne, O sztuce rozumowania, [w:] idem, Próby, t. 3..., s. 171. Por. M. de Montaigne, Apologia..., s. 137, 182, 258.

42 Por. M. de Montaigne, Apologia..., s. 172. „Zaiste, bardzo przepłaciliśmy ten rozum, którym się chełpimy, i tę zdolność sądzenia i poznania, jeśli kupiliśmy je za cenę tej nieskończonej liczby namiętności, których jesteśmy nieustannym łupem!" (ibidem s. 170).

43 Ibidem, s. 276. Te stwierdzenia Montaigne'a dotyczące istoty rzeczy, w świetle poglądów sceptycznych Sekstusa Empiryka, nie są stanowiskiem sceptyka, lecz dogmatyka. „[...] dogmatyk zakłada rzeczywiste istnienie tego, o czym dogmatyzuje, a sceptyk wygłasza powiedzenia w taki sposób, iż się znaczeniowo Same obalają" (Sekstus Empiryk, Zarysy pirrońskie, tłum. A. Krokiewicz, Warszawa 1998, s. 17). Zdaniem Sekstusa sceptyk dopuszcza myśl, że pewne rzeczy może i dają się uchwycić, a ponieważ on ich jeszcze nie odnalazł, to nic o nich nie może powiedzieć pewnego. Por. Sekstus Empiryk, op. cit., s. 59 .

${ }^{44}$ M. de Montaigne, $O$ żalu, [w:] idem, Próby, t. 3..., s. 54. 
i Było, i Będzie, które to słowa zaraz z pierwszym wejrzeniem wskazują oczywiście, iż to nie jest rzecz, która jest ${ }^{45}$.

Montaigne powtarza prawie dosłownie Arystotelesowską definicję czasu, według której czas jest ilością ruchu wedle tego, co przed i po ${ }^{46}$. Czas nie jest niczym innym, jak rzeką teraz: „teraz — jeszcze — nie”, „teraz” oraz „teraz — już — nie”. „Teraz" brane samo w sobie jest mgnieniowe i jako takie jest nieuchwytne w poznaniu, ponieważ natychmiast zapada się w przeszłość. Rozum, chcąc uchwycić coś trwałego w poznawanej rzeczy (jej istotę), ponosi porażkę, ponieważ pod wpływem czasu „to nie jest rzecz, która jest”, ale której już nie ma. W konsekwencji ,istotą wszystkich rzeczy jest przechodzić z jednej odmiany w drugą, rozum, który szuka $\mathrm{w}$ nich prawdziwego istnienia, spotyka się z zawodem, nie mogac nic pochwycić ciągłego ani trwałego"47. Odnosząc nieuchwytność czasu (teraz) do zrozumienia istoty człowieka, Montaigne twierdzi, że

[o]statecznie trzeba nam uznać, iż nie ma żadnego stałego istnienia, ani w naszej istocie, ani w innych przedmiotach; i my, i nasz sąd, i wszystkie rzeczy śmiertelne toczą się i płyną bez ustanku. Nie da się tedy nic ustalić pewnego z jednego o drugim, gdyż i sądzący podmiot, i sądzone przedmioty znajdują się w nieustannej odmianie i ruchu ${ }^{48}$.

W związku z tym, że wszystko jest zmienne, człowiek nie ma żadnej możliwości zrozumienia ani samego siebie, ani rzeczy istniejących poza nim.

To, co ulega zmianie, nie zostaje tożsamym; a jeśli nie jest tożsamym, znaczy, że nie jest wcale. Albowiem, gdy zmienia się pewien byt, zmienia się byt w ogóle, czyli samo istnienie, przemieniając się wciąż z jednego w drugi ${ }^{49}$.

W poznaniu rzeczy mamy do czynienia tylko z „mglistym pozorem cieni” i niepewnymi „rojeniami” ich dotyczącymi.

\section{Przypadek zamiast metody}

Zmienność stanowiąca integralną część ludzkiej kondycji jest niesceptycznym założeniem przyjętym przez Montaigne’a w Próbach. Wiąże się ona z przyjęciem przez niego ontologicznego założenia dotyczącego świata, a mianowicie tego, że istnieje rzeczywistość transcendentalna wobec nas, do której w poznaniu zarówno zmysłowym, jak i umysłowym nie mamy dostępu.

Następną oprócz zmienności niesceptyczną postawą Montaigne'a, którą można dostrzec w Próbach, jest jego zadziwiająca łatwowierność, którą trudno pogodzić z fundamentalnym krytycyzmem sceptyków. Należy jednak pamiętać, że historie przez niego przytoczone były gwarantowane autorytetem Plutarcha, od którego

45 M. de Montaigne, Apologia..., s. 278.

${ }^{46}$ Por. Arystoteles, Fizyka, tłum. K. Leśniak, [w:] idem, Dzieła wszystkie, t. 2, tłum. K. Leśniak et al., Warszawa 1990, s. 107.

47 M. de Montaigne, Apologia..., s. 277.

48 Ibidem, s. 276-277. Montaigne, przyjmując za Heraklitem ontologiczne założenie, że istotą bytu jest zmienność — panta rei, czyli że nie ma nic stałego ani w poznającym podmiocie, ani w poznawanej rzeczywistości, jawnie odrzuca epikurejską wersję niewzruszalności boskiej. Por. ibidem, s. 177.

49 Ibidem, s. 278. 
w większości zostały zapożyczone często niemal dosłownie i że wiele z tych legend zostało przyjętych także bez zastrzeżeń przez uczonych w XVI wieku.

Z niesceptyczną, „pozorną” łatwowiernością mamy do czynienia w eseju O potędze wyobraźni, w którym Montaigne powtarza opowieści, które są co najmniej fantastyczne. Na koniec przytoczonych anegdot dodaje, że jest świadom tego, co robi i tłumaczy, dlaczego tak postępuje. Po opowiedzeniu historii o kocie ${ }^{50}$, który samym spojrzeniem sprawił, że ptak spadł z drzewa, a następnie o sokolniku, który także mocą samego spojrzenia spowodował upadek jastrzębia, Montaigne wyjaśnia cel przytoczenia tych nieprawdopodobnych opowieści:

w tym traktowanym przeze mnie studium naszych obyczajów i namiętności świadectwa bajeczne, byle tylko możebne, służą mi równie dobrze, jak prawdziwe: zdarzyło się czy nie zdarzyło, w Rzymie czy w Paryżu, Pawłowi czy Gawłowi, zawsze to obraz z zakresu ludzkiej możliwości i opowieść taka zawżdy przynosi mi jakowyś pożytek. Oglądam i czerpię wiedzę zarówno patrząc na cień, jak na przedmiot rzeczywisty [...]. Bywają autorowie, dla których celem jest opowiadać, co się zdarzyło; ja gdybym potrafił, miałbym za cel rozprawiać o tym, co może się zdarzyćc ${ }^{51}$.

Tym celem jest zwrócenie uwagi czytelnika na prawdopodobieństwo, na to, „co może się zdarzyć" ${ }^{\prime 52}$.

Podobnie w rozdziale zatytułowanym Obrona Seneki i Plutarcha Montaigne broni Plutarcha przed oskarżeniem Jana Bodeniusza o ,nieuctwo” oraz o zbytnią łatwowierność w przytaczaniu przez niego rzeczy niepodobnych do wiary i na wskroś bajecznych ${ }^{53}$.

Czy coś jest możliwe lub nie, nie trzeba o tym wyrokować wedle tego, co jest wiarygodne a niewiarygodne w naszym rozumieniu, jako już rzekłem gdzie indziej. Jest to wielki błąd, w który wszelako popada większość (nie mówię tego do Bodeniusza), niż niełacno wierzą u drugich w to, czego nie umieliby albo nie chcieli uczynić sami. Zdaje się każdemu, iż najwyższa forma natury ludzkiej mieści się w nim samym: wedle niej trzeba miarkować wszystkie inne: rysy niepodobne do jego rysów są udane i fałszywe. O cóż za tępość i głupota ${ }^{54}$.

Pozorna łatwowierność Montaigne’a wynika z przyjętej przez niego postawy sceptycznej, różniącej się od sceptycyzmu starożytnego. Nie zawiesza on sądu dotyczącego możliwości poznania świata zewnętrznego, dlatego też nie odrzuca istnienia w nim tego, co niezrozumiałe, niesamowite i jako takie trudne do pojęcia przez rozum ludzki. W swoim sceptycyzmie jest otwarty na możliwości, na pojawienie się w poznaniu tego, co nieznane i prawdopodobne. Przez podkreślenie znaczenia możliwości w poznaniu odkrywa on „wielki błąd” naszego rozumowania, który swoimi korzeniami sięga starożytnej Grecji. To Protagoras uczynił człowieka miarą wszystkich rzeczy. Następstwem przyjęcia jego stanowiska epistemologicz-

${ }^{50}$ Por. M. de Montaigne, O potędze wyobraźni, [w:] idem, Próby, t. 1..., s. 224.

51 Ibidem, s. 224.

${ }^{52}$ Arystoteles postępuje podobnie w Poetyce, ceniąc bardziej poetów niż historyków: „poezja jest bardziej filozoficzna i poważna niż historia; poezja wyraża przecież to, co ogólne, historia natomiast to, co jednostkowe" (Arystoteles, Poetyka, tłum. H. Podbielski, [w:] idem, Dzieła wszystkie, t. 6, tłum. H. Podbielski et al., Warszawa 2001, s. 588).

${ }^{53}$ Por. M. de Montraigne, Obrona Seneki i Plutarcha, [w:] idem, Próby, t. 2..., s. 376.

${ }^{54}$ Ibidem, s. 379. 
nego jest odrzucenie tego wszystkiego, co wykracza poza nasze dotychczasowe doświadczenie, czyli odrzucenie tego, czego nie jesteśmy w stanie zrozumieć ${ }^{55}$.

Montaigne, podkreślając w Próbach znaczenie ontologicznych możliwości, które wymykają się naszemu rozumieniu i wydają się „majakami i bredzeniem”, samego siebie nazywa „nieumyślnym i przygodnym filozofem"56. Według niego to przypadek, a nie metoda decyduje o przyjęciu przez nas takiej, a nie innej koncepcji poznania ${ }^{57}$. Siebie samych zastajemy ,wrzuconych" przez ślepy los w określony sposób poznawania świata. Sam był świadkiem, jak przyjęcie opinii panującej w społeczeństwie za prawdę zrodziło dogmatyzm w myśleniu i fanatyzm w działaniu, w konsekwencji doprowadzając do wojen religijnych ${ }^{58}$. Ratunkiem dla nas, aby nie ulec przesądom, w których tkwimy, jest zachowanie zdrowego rozsądku i nieprzyjmowanie za prawdę opinii głoszonych przez innych ${ }^{59}$. Oprócz przypadku wyznacznikiem swojej filozofii Montaigne czyni możliwość. Możliwości nie da się logicznie zaplanować, aby ją następnie metodycznie realizować, ponieważ każda możliwość związana jest z tym, co przypadkowe i nieprzewidywalne ${ }^{60}$. Każda sytuacja, w której się znajdujemy, i każda rzecz, z którą mamy do czynienia, stwarzają wiele równorzędnych możliwości ${ }^{61}$. W wyborze określonej możliwości powinniśmy kierować się nie rozumem, lecz intuicją ${ }^{62}$.

\section{Poznanie samego siebie — „co ja wiem?"}

Po podważeniu możliwości poznania zarówno zmysłowego, jak i rozumowego Montaigne mógł wzorem starożytnych sceptyków stwierdzić, że we wszystko wątpi albo że niczego nie wie. On jednak wybrał inną możliwość — zwrócił się ku poznaniu samego siebie: „Ludzie patrzą zawsze na zewnątrz, ja zasię kieruję wzrok ku wnętrzu: tam go zatrudniam, tam go bawię. Każdy patrzy przed siebie, ja w sie-

${ }^{55}$ Przykłady, które przytacza Montaigne w Próbach, chociaż wydają się nierealne, to jednak ich istnienie jest możliwe, ponieważ nie są logicznie sprzeczne. W ten sposób Montaigne niejako staje się prekursorem empiryzmu D. Hume'a. Por. D. Hume, Badania dotyczace rozumu ludzkiego, tłum. J. Łukasiewicz, K. Twardowski, Warszawa 1977, s. 33-34.

56 Por. M. de Montaigne, Apologia..., s. 226.

${ }^{57}$ Por. ibidem, s. 186-187.

${ }^{58}$ Por. ibidem, s. 187.

${ }^{59}$ Por. ibidem.

${ }^{60}$ Por. M. de Montaigne, O Demokrycie i Heraklicie, [w:] idem, Próby, t. 1..., s. 387; M. de Montaigne, Apologia..., s. 242. Podkreślenie przez Montaigne'a ważności możliwości w ontologii, jak również ukazanie jej wyższości w rozumieniu, powoduje, że staje się on prekursorem metody fenomenologicznej w filozofii. W fenomenologii „otwiera się możliwość budowania czystej ontologii, która nie liczy się z faktycznie zrealizowanymi istotami, konkretnymi treściami, lecz bada możliwości, czyste stany rzeczy, czyste istoty rzeczy, zastanawia się nad możliwymi związkami między ich elementami i między nimi samymi, a także nad tym, do zaistnienia jakich ogólnych struktur to wszystko prowadzi, wreszcie zaś, co z owych powiązań i struktur ostatecznie wynika. Okazuje się przy tym, że świat możliwości jest znacznie bogatszy, znacznie rozleglejszy, aniżeli ten, który jest faktycznie realizowany. Na tym właśnie polega rola metody fenomenologicznej" (W. Stróżewski, P. Taranczewski, Wyktady lubelskie o estetyce, Kraków 2016, s. 74).

${ }^{61}$ Por. M. de Montaigne, O mówieniu powolnym i rychtym, [w:] idem, Próby, t. 1..., s. 168.

${ }^{62}$ Por. M. de Montaigne, O przepowiedniach, [w:] idem, Próby, t. 1..., s. 172. 
bie" . W . eseju $O$ wychowaniu dzieci stwierdza expressis verbis, że przedmiotem swoich badań uczynił siebie: „Celem moim jedynym jest odkryć samego siebie..."64. W związku ze zmianą perspektywy badawczej stawia pytanie dotyczace własnej wiedzy: „que sais-je?” („co ja wiem?”) ${ }^{65}$. Chociaż postawienie tego pytania może sugerować sceptyczne zawieszenie sądu ${ }^{66}$, to zdaniem I. Dąmbskiej pozwoliło ono Montaigne'owi przede wszystkim uniknąć zarzutu samorefutacji:

Ten bowiem, kto tak się wyraża, unika zarzutu, że zaprzeczając sam sobie, głosi pewną tezę z pretensją do pewności, tę mianowicie, że wszystko jest niepewne i wątpliwe. To pytanie umieścił też Montaigne - jak sam opowiada — w postaci napisu nad wagą. Waga zaś była w starożytności symbolem sceptycznej zasady izostenii ${ }^{67}$.

Montaigne, czyniąc samego siebie przedmiotem poznania, stał się pierwszym nowożytnym odkrywcą jaźni, a przez to ojcem nowoczesnej podmiotowości ${ }^{68}$. Dlatego zwrócił się do własnej jaźni, ponieważ był przekonany, że próba przedstawienia najwierniejszego autoportretu może doprowadzić go do lepszego zrozumienia ludzkiej natury:

Każdy człowiek nosi całkowitą postać ludzkiego stanu. Zazwyczaj autorowie udzielają się publiczności jakowąś osobną i szczególna cechą; ja. Pierwszy pono, całą mą istotą: jako Michał z Montaigne, nie jako gramatyk albo poeta, albo uczony w prawie ${ }^{69}$.

Stawiając pytanie o to, „co ja wiem?”, zastosował nowy, sceptyczny styl mówienia, który wyraża się przez pytania, zamiast dotychczasowego, nakierowanego na odpowiedzi twierdzace. W duchu umiarkowanego sceptycyzmu proponuje używać form wypowiedzi, które powstrzymają ludzi od dogmatycznego zajmowania stanowiska: „zdaje mi się”, „być może”, „poniekąd”, „po części”, „powiadają”, „mniemają”

${ }^{63}$ Por. M. de Montaigne, O zarozumiałości, [w:] idem, Próby, t. 2..., s. 326.

${ }^{64}$ Por. M. de Montaigne, O wychowaniu dzieci, [w:] idem, Próby, t. 1..., s. 261.

${ }^{65}$ Por. M. de Montaigne, Apologia..., s. 208. Montaigne dostrzega problem z przedstawianiem własnego stanowiska przez pirrończyków: „Trzeba by im nowego języka: nasz cały język ukształtowany jest ze zdań twierdzących, które im są ze wszystkim przeciwne; tak iż gdy mówią »wątpię«, można im natychmiast ścisnąć gardło i zmusić do wyznania, iż przynajmniej twierdzą i wiedzą to, że wątpią" (ibidem, s. 208).

66 Por. ibidem, s. 208, 187.

${ }^{67}$ I. Dąmbska, Sceptycyzm francuski..., s. 32. W związku z tą wypowiedzią Dąmbskiej wydaje się jednak trafna uwaga R. Ziemińskiej, że pomysł Montaigne'a, aby zdania oznajmujące zastąpić pytającymi, którego nie wykorzystali sceptycy starożytni, jest nowatorski: „Może to świadczyć o dużej kulturze logicznej, jakiej dopracowała się filozofia średniowieczna. W świetle jednak współczesnych badań nad językiem, trzeba uznać propozycje Montaigne'a — wbrew temu, co pisze Dąmbska — za nieskuteczne. Samo bowiem postawienie pytania niesie ze sobą założenia, w tym poznanie znaczenia słów i własnych myśli, a zatem zakłada samowiedzę i znajomość języka. Te zaś nie są niezależne od wiedzy o świecie zewnętrznym" (R. Ziemińska, Michel de Montaigne..., s. 208-209).

68 Por. G. Paganini, op. cit., s. 241.

${ }^{69}$ M. de Montaigne, O żalu, [w:] idem, Próby, t. 3.., s. 54. Poznanie samego siebie dawało mu możliwość poznania innych: „człowiek nie może się wznieść wyżej siebie i ludzkości: nie może widzieć inaczej niż swymi oczami ani ogarnąć inaczej niż swoim pojęciem” (M. de Montaigne, Apologia..., s. 279). Razem z Sokratesem podzielał maksymę wyrytą na frontonie świątyni Apollina w Delfach: „Poznaj samego siebie” (łac. „Nosce te ipsum”, gr. „Gnothi se auton”). 
i dodaje, że gdyby wychowanie dzieci zależało od niego, to by im wpoił od dzieciństwa „ów sposób odpowiadania, szukający, a nie rozstrzygający"70.

Montaigne, poznając samego siebie, ma świadomość, że ma do czynienia z wiedzą prawdopodobną, a nie pewną. W eseju $O$ ksiażkach zaznacza, że: „To, co tu daję, to są moje urojenia, przez które nie staram się bynajmniej dać poznać samych rzeczy, jeno siebie",71. I dodaje:

Nie szukam w książkach nic, jak jeno uciszenie, a przystojnej zabawy: albo też jeśli w nie wnikam głębiej, szukam jeno wiedzy, która traktuje o znajomości samego siebie i która by mnie nauczyła dobrze żyć i dobrze umierać: Has meus ad metas sudet oporet equus ${ }^{72}$.

Aby uniknąć niepotrzebnego uwikłania się w spory dotyczące poznania rzeczy, zaleca pragmatyczne podejście do życia. Należy używać każdej rzeczy podług jej najlepszego zastosowania w praktycznych potrzebach. A to znaczy, że należy brać „każdą rzecz wedle jej prawdziwej wartości, wedle tego, jak mu jest najbardziej użyteczną i sposobną do życia"73.

Człowiek jest „badaczem bez wiedzy”, „sędzią bez władzy i ostatecznie, błaznem z szopki", ale mimo wszystko musi starać się poznać siebie i zrozumieć swoje miejsce w świecie. Ostatecznie nawet z poznaniem samego siebie mamy pewne trudności - mianowicie skąd pewność, że i w tym przypadku nie ulegamy iluzji zmysłów i samookłamywania przez rozum. Według Elaine Limbrick nieufność do rozumu doprowadziła Montaigne'a do fideizmu ${ }^{74}$.

\section{Zwrot ku fideizmowi}

Apologia kończy się stwierdzeniem, że tylko wiara może wznieść człowieka ponad jego ograniczenia w komunikacji z odwiecznym Bogiem ${ }^{75}$. Montaigne przyznaje, że „dzięki łasce bożej zachowałem się cały, bez wstrząśnień i zamętu sumienia, w dawnych wierzeniach naszej religii, pośród tylu sekt i odszczepieństw, jakie nasze czasy wydały"76. Jego zwrot od sceptycyzmu do wiary jest główną podstawą poglądu, że był on sceptykiem chrześcijańskim, sceptykiem fideistą 77 . Montaigne'owi

${ }^{70}$ Por. M. de Montaigne, O kulawych, [w:] idem, Próby, t. 3..., s. 251. Według A. Hartle, taki sposób mówienia wskazuje, że Montaigne jest sceptykiem chrześcijańskim. Por. A. Hartle, op. cit., s. 187.

${ }^{71}$ M. de Montaigne, O ksiazkkach, [w:] idem, Próby, t. 2..., s. 104.

72 Ibidem, s. 105-106.

${ }^{73}$ M. de Montaigne, Apologia..., s. 171-172.

${ }^{74}$ Por. E. Limbrick, Montaigne et Saint Augustin, „Bibliotheque d'Humanisme et Renaissance” 34 (1972), s. 58-59.

${ }^{75}$ Por. M. de Montaigne, Apologia..., s. 279. Zdaniem Popkina Montaigne wierzył za św. Augustynem, że człowiek może być oświecony tylko przez Boga, ale w odróżnieniu od autora Wyznań, nie twierdził, że tego oświecenia doświadczy choćby częściowo. Por. R.H. Popkin, op. cit., s. XVI.

${ }^{76}$ M. de Montaigne, Apologia..., s. 248. „Wiara nasza to nie jest nasza zdobycz: to prosty dar cudzej hojności. Nie mocą naszego rozumu ani pojęcia otrzymaliśmy naszą religię; jeno mocą cudzej powagi i nakazu" (ibidem, s. 183).

${ }^{77}$ Por. A. Hartle, op. cit., s. 191. „Fideizm wystąpił już w poglądach starożytnych sofistów i we wczesnym okresie patrystyki (Tertulian); obniżenie oceny rozumu było reakcją niektórych chrześcijan na przesiąkniętą sceptycyzmem filozofię pogańską. Wyraźnie też ujawnił się w średniowiecznej myśli arabskiej w pismach al. Ghazalego (zm. 1111), który filozofii Awicenny przeciwstawił wiarę w prawdzi- 
przyszło żyć w czasach głębokiego kryzysu ${ }^{78}$, dlatego w jego zamyśle Apologia Rajmunda Sebond miała być obrona wiary katolickiej przed atakami zarówno ateistów, jak i reformacji ${ }^{79}$.

Po pierwsze, szesnastowieczna Francja była dotknięta kryzysem religijnym, wywołanym przez reformację, który zbiegał się z ponownym odkryciem i odrodzeniem argumentów starożytnych sceptyków. Gdy reformatorzy własnymi rozumowymi kontrargumentami zwalczali ustalone zasady wiary, to sceptyczne argumenty używane przez katolików wykazywały, że rozum ludzki nie nadaje się do rozstrzygania sporów teologicznych. W ten sposób tradycja, czyli katolicka doktryna, znalazła sojusznika w sceptycyzmie. Obronę doktryny katolickiej za pomocą argumentów sceptycznych nazwano ,sceptycznym fideizmem” ${ }^{\text {" }}$.

Montaigne, biorąc pod uwagę niezdolność rozumu do odkrycia kryterium prawdziwej wiary, również proponuje sceptycyzm jako jej „obronę"81. Apologia tak jak całość Prób stała się narzędziem kontrreformacji w zwalczaniu protestantyzmu. Była traktowana jako świecka apologia katolicyzmu, a Montaigne był uważany za mistrza filozofii stoickiej i chrześcijańskiej ${ }^{82}$. Na poglądy „chrześcijańskiego sceptyka”, głoszące bezsilność rozumu ludzkiego w poznaniu prawdy bez pomocy łaski Bożej,

wość Koranu. Jawny fideizm w zakresie teologii głosił Ockham, wg którego jedynie przez wiarę możemy osiągnąć pewność istnienia Boga, nieśmiertelności duszy i prawa moralnego, podobne poglądy podzielał Mikołaj z Autrecourt, Pascal i P.D. Huet" (Z. Chlewiński, Fideizm, [w:] Leksykon Filozofii Klasycznej, J. Herbut (red.), Lublin 1997, s. 197).

78 Por. R.H. Pokin, op. cit., s. 53-54.

79 Jednak charakter tej obrony dał początek rozbieżnym interpretacjom deklarowanej szczerości Montaigne'a w sprawach wiary. Niektórzy uważali go za ukrywającego się ateistę lub agnostyka, który krytykuje ateizm, żeby samemu uniknać prześladowań. Inni uznawali go za sceptyka fideistę, który uznaje wartość religii ze względu na zachowanie pokoju społecznego. Według A. Hartle Montaigne był sceptykiem fideistą, który próbował pogodzić sceptycyzm ze szczerym wyznaniem wiary. Por. A. Hartle, op. cit., s. 191. Philippe Desan uważa, że Montaigne nigdy nie zachwiał się w swojej wierze katolickiej, chociaż Próby obfitują w krytykę praktyk religijnych i często przedstawiają sądy sprzeczne z oficjalnym stanowiskiem Kościoła rzymskokatolickiego. Por. Ph. Desan, Montaigne: a life, tłum. St. Rendall, L. Neal, New Jersey 2017, s. 614-615.

${ }^{80}$ Por. A. Hartle, op. cit., s. 187; por. T. Penelhum, God and Skepticism: A Study in Skepticism and Fideism, Dordrecht 1983, s. 15, 23; por. D. Leszczyński, op. cit., s. 118.

${ }^{81}$ Vázquez uważa, że sceptycyzm Montaigne’a był częścią poszukiwań przez niego wiary. Por. M.B. Vázquez, op. cit., s. 60. Podstawową cechą chrześcijańskiej tradycji sceptycznej, podzielaną przez Montaigne'a, był prymat wiary nad rozumem wynikający z granic ludzkiego rozumu.

82 Jeżeli chodzi o stosunek Montaigne'a do ruchów reformatorskich, to był on w przeważającej części negatywny. Reformacja była dla niego jak zakaźna choroba, z której należało się wyleczyć. W Próbach poddaje krytyce wystąpienie Lutra, zapoczątkowujące ruch reformatorski w Kościele: „Było to wówczas, kiedy nowinki Lutra zaczęły zdobywać sobie grunt i w wielu miejscach ochwiewać naszac dawną wiarę. Piotr Bunel bardzo trafnie patrzył na to, przewidujacc bystrym rozumem, iż ów poczatek choroby wyrodzi się niebawem w obmierzłą bezbożność" (M. de Montaigne, Apologia..., s. 128-129). Zdaniem Montaigne'a to zbytnie zaufanie Lutra i jego zwolenników do rozumu doprowadziło do podziału chrześcijaństwa na dwa zwaśnione obozy i w konsekwencji do wojen religijnych. Na początku Apologii Montaigne potępia reformację, ponieważ zamiast deklarowanej reformy religii doprowadziła ludzi do wzajemnej nienawiści i ateizmu. Jednak mimo negatywnego stosunku do protestantyzmu nie przeszkodziło mu to w nawiązywaniu z nimi przyjaznych stosunków. Apologię Rajmunda Sebond dedykował Małgorzacie Valois, która była żoną wodza hugenotów Henryka, króla Nawarry. W 1577 roku Henryk mianował Montaigne'a swoim szambelanem. Por. Z. Gierczyński, op. cit., s. 24-25. 
powoływali się między innymi: Pierre Charron, biskup Pierre Camus oraz św. Franciszek Salezy.

Jednak z czasem wzrastała liczba libertynów, którzy uznawali Montaigne’a za swego zwolennika i pogromcę wszelkiego zabobonu. Wśród jego zwolenników, którzy uważali go za swego prekursora znaleźli się: Montesquieu, Wolter i Diderot ${ }^{83}$.

Pascal dowodził, że autor Prób nie był aż tak dobrym katolikiem, żeby uczynić go wzorem dla wierzacych. Janseniści z Port-Royal siedemdziesiąt cztery lata po śmierci Montaigne'a w 1666 roku przystąpili do frontalnego ataku na jego filozofię, uważając, że jego przychylność wobec Kościoła była chytrze udawana, aby ukryć wrogość wobec niego. Do potępienia jego twórczości przyłączył się w 1674 roku Malebranche, a w dwa lata później Próby trafiły na Indeks Ksiąg Zakazanych ${ }^{84}$.

To wydarzenie przypieczętowało koniec sojuszu katolików ze sceptycyzmem. Według badań Popkina ${ }^{85}$ przymierze trwało mniej więcej od zakończenia soboru trydenckiego (1545-1563) do odwołania edyktu nantejskiego w roku 1685, aż Francja znów stała się toute Catholique, a sceptyków uznano za wrogów kościoła.

Drugim przejawem kryzysu XVI wieku był kryzys społeczny związany z odkryciem Nowego Świata. Okazało się, że po drugiej stronie Oceanu Atlantyckiego istnieje inny świat kulturowy. Ponownie pojawiło się pytanie o kryterium prawdziwości obyczajów, religii i głoszonych poglądów. Na jakiej podstawie można ocenić, czy perspektywy ,szlachetnych dzikusów” są lepsze, czy gorsze od naszych własnych?

Trzecim, najbardziej znaczącym symptomem kryzysu, na który wskazuje Montaigne i który pogłębia w Próbach, był kryzys wiedzy naukowej. W epoce, w której cały naukowy paradygmat wiedzy opartej na filozofii Arystotelesa został zaatakowany i podważony, rozszerzenie religijnego i społecznego kryzysu na świat naukowy groziło zniszczeniem możliwości osiągnięcia wiedzy pewnej. Montaigne stwierdza w Apologii, że tylko wiara w autorytet Bożego objawienia ${ }^{86}$ może wyzwolić człowieka z jego skończoności i uwikłania się w błędy poznawcze i umożliwić mu osiągnięcie prawdy ${ }^{87}$. To odwołanie się autora Prób do autorytetu Objawienia Bożego w poznaniu, jak podkreśla Dąmbska, było całkowicie obce duchowi filozofii greckiej $^{88}$. Było to tym bardziej niebezpieczne, że zacierało granicę między nauką i wiarą, czego z taką siłą doświadczył Galileusz.

${ }^{83}$ Por. Z. Gierczyński, op. cit., s. 75-77.

${ }^{84}$ Por. Ph. Desan, op. cit., s. 621. Rzymska cenzura sformułowała dwa zastrzeżenia wobec Prób: zbytnią niefrasobliwość w części dotyczącej historii Kościoła oraz zbyt dużą liczbę cytowanych nieprzyzwoitych anegdot, które uczyniły z nich niemoralną książkę. Choć oczywiście były to anachroniczne zarzuty w odniesieniu do okresu, w którym wulgarny język był znacznie bardziej powszechny niż w XVI wieku. Pomimo tych zarzutów nadal można było wydawać Próby, ale bez kontrowersyjnych fragmentów.

${ }^{85}$ Por. R.H. Popkin, Skepticism and the Counter-Reformation in France, „Archiv für Reformationsgeschichte - Archive for Reformation History" 51 (1960), s. 85.

${ }^{86}$ Por. M. de Montaigne, Apologia..., s. 189, 242.

${ }^{87}$ Por. ibidem, s. 279.

${ }^{88}$ Por. I. Dąmbska, Sceptycyzm francuski..., s. 20. 


\section{Podsumowanie}

Przyjęte przez Montaigne'a założenia w epistemologii doprowadziły go do totalnego sceptycyzmu w poznaniu. Podstawowym założeniem przyjętym przez niego w poznaniu był empiryzm genetyczny i metodologiczny — cała wiedza pochodzi od zmysłów i dochodzi do nas za ich pośrednictwem. Tak zdobyta wiedza okazała się jednak niepewna, ponieważ zmysły narażone są na ułudę. Kolejnym jego założeniem był wariabilizm ontologiczny, pochodzący od Heraklita — istotą rzeczy jest jej zmienność, dlatego nie jesteśmy w stanie uchwycić jej tożsamości. W związku z nim poznanie świata zewnętrznego jest niemożliwe. Wiedza o nim jest dla nas niedostępna.

Konsekwencją przyjętego przez Montaigne'a pierwszego założenia jest brak „pomostu” między rzeczą a jej wrażeniem odbieranym przez nasz umysł. Wniosek, jaki wypływa z drugiego założenia, przekreśla wszelką możliwość poznania. Żadna zastosowana metoda badawcza nie umożliwi nam poznania rzeczy, ponieważ ze swej natury jest ona nieuchwytna. Jeżeli wiedza o świecie zewnętrznym jest niemożliwa, to naturalną koleją rzeczy jest pytanie o własną wiedzę: „co ja właściwie wiem?". Wiedza o świecie zewnętrznym jest nieosiągalna, zatem pytanie dotyczy wiedzy pochodzącej z doświadczenia wewnętrznego. Badania własnej jaźni nie miały jednak na celu ukazania tego, co uniwersalne w naturze ludzkiej, lecz poznanie własnej indywidualności ${ }^{89}$. Studia nad samym sobą doprowadziły go do uchwycenia tego, co jednostkowe i przypadkowe ${ }^{90}$. Montaigne nie przewidział jednak, że poznanie własnej jaźni bez wyznaczenia celu badania i określonej metody okaże się dla niego źródłem wszelkich niepewności ${ }^{91}$. We własnym wnętrzu odkrył tylko niepewność spowodowaną chaosem odbieranych wrażeń. Jeżeli wszystko w poznaniu jest niepewne, to pojawia się problem związany z codziennym życiem. Z pomocą Montaigne'owi przychodzi jego wiara - fideizm. Lekarstwem na złudę zmysłów i kłamstwo rozumu jest objawienie Boże i prawda z nim związana. Odpowiedzią na destrukcyjne wnioski płynące ze sceptycyzmu Montaigne'a dla możliwości stworzenia wiedzy pewnej była filozofia Kartezjusza.

Kartezjusz, chcac zbudować od podstaw nowy gmach wiedzy ${ }^{92}$, musiał zmierzyć się z kryzysem epistemologicznym wzmocnionym przez Montaigne’a. Według autora Prób wygląd zewnętrzny oszukuje umysł, ale bardziej niepokojące jest to,

${ }^{89}$, ,...] pełne sformułowanie nowożytnego pytania o tożsamość pojawiło się dopiero w okresie postromantycznym, czego wyrazem była, centralna dla Herderowskiego ekspresywizmu, idea, że każdej osobie przypisany jest osobny, oryginalny sposób istnienia [...]. Myśl Montaigne’a niewątpliwie przyczyniła się do ukonstytuowania naszego rozumienia podmiotu" (Ch. Taylor, Źródta podmiotowości. Narodziny tożsamości nowoczesnej, tłum. M. Rychter et al., Warszawa 2001, s. 343).

90 Zdaniem Taylora „Montaigne zapoczątkował nową odmianę silnie zindywidualizowanej refleksji - badania samego siebie, polegające na przedzieraniu się przez zasłony utkane ze złudzeń zrodzonych przez namiętność i duchową dumę" (ibidem, s. 338-339).

${ }^{91}$ Por. L. Dupré, Passage to modernity. An Essay in the hermeneutics of Nature and Culture, Yale 1993, s. 116.

${ }^{92}$ Zgodnie z przedstawioną przez Kartezjusza metaforą drzewa wiedzy z korzenia metafizyki wyrasta filozofia przyrody (fizyka) oraz trzy jej wielkie dyscypliny: medycyna, mechanika i etyka (R. Descartes, Autor do tłumacza ksiazki, [w:] idem, Zasady filozofii, tłum. I. Dąmbska, Kęty 2001, s. 19). 
że umysł oszukuje sam siebie tak, że natura jaźni jest źródłem wszelkiej niepewności. Autor Rozprawy o metodzie w odróżnieniu od Montaigne’a jest dzieckiem rewolucji naukowej, jest pełen wiary w możliwość rozwoju nauki, opiercając się na niepodważalnym fundamencie, który chce znaleźć. Nauczony porażką Montaigne'a nie redukuje podmiotu poznania do ,ja” Kartezjusza. W jego rozumieniu podmiot poznania ma być natury ogólnej, konstruowany przez bezosobowy rozum, kierujący się uniwersalnymi kryteriami odnoszącymi się do wszystkich przedstawicieli tego samego gatunku ${ }^{93}$. Kartezjusz zgadza się z Montaigne'em, że zmysły nie są wiarygodnym pośrednikiem poznania, ale w przeciwieństwie do autora Prób dąży do wiedzy prawdziwej, aby przywrócić więź poznania ze światem zewnętrznym. Sceptyczne wątpliwości nie są tylko przeszkodą, którą należy pokonać, lecz służą mu w drodze do osiągnięcia absolutnej pewności, oczyszczając poznanie z wszelkiego błędu i fałszu. We wnętrzu samego siebie, w cogito ergo sum odnalazł punkt archimedesowy pewności poznania. Ale droga do zbudowania nowego gmachu wiedzy pewnej była jeszcze daleka. Przede wszystkim odkrycie jednej absolutnej prawdy, jaką jest cogito, obalało sceptyczne nastawienie wobec poznania, że wszystko jest niepewne, ale jedna prawda nie mogła stanowić systemu wiedzy o rzeczywistości. Ukazanie kolejnych etapów rozwoju myśli Kartezjusza, prowadzących poza zwątpienie Montaigne'a ku wiedzy pewnej o świecie zewnętrznym, wykracza poza tematykę tego artykułu. Na zakończenie naszych rozważań należy zaznaczyć, że smutnej historii opowiedzianej przez Montaigne'a, opowieści o klęsce rozumu wobec sceptycyzmu Kartezjusz przeciwstawił swoją historię zwycięstwa rozumu i metody nad zwątpieniem w poznanie.

\section{Bibliografia}

Arystoteles, Fizyka, tłum. K. Leśniak, [w:] idem, Dzieła wszystkie, t. 2, tłum. K. Leśnmiak, A. Paciorek, L. Regner, P. Siwek, Warszawa 1990.

Arystoteles, O duszy, tłum. P. Siwek, [w:] idem, Dzieła wszystkie, t. 3, tłum. P. Siwek, Warszawa 1992.

Arystoteles, Poetyka, tłum. H. Podbielski, [w:] idem, Dzieła wszystkie, t. 6, tłum. H. Podbielski et al., Warszawa 2001.

Brahami Fr., Le scepticisme de Montaigne, Paris 1997.

Chlewiński Z., Fideizm, [w:] Leksykon Filozofii Klasycznej, J. Herbut (red.), Lublin 1997. Dąmbska I., Sceptycyzm francuski XVI i XVII wieku, Toruń 1958.

Dąmbska I., Zagadnienia marzeń sennych w greckiej filozofii starożytnej, [w:] eadem, Znaki i myśli, Warszawa 1975.

Desan Ph., Montaigne: a life, tłum. St. Rendall, L. Neal, New Jersey 2017.

Descartes R., Autor do tłumacza ksiażki, tłum. I. Dąmbska, [w:] idem, Zasady filozofii, tłum. I. Dąmbska, Kęty 2001.

${ }^{93}$ Podmiot kartezjański jest antytezą podmiotu Montaigne’a. Por. Ch. Taylor, op. cit., s. 340. Koncepcja Kartezjańskiego podmiotu zbliża się do tego, co Kant nazwał później transcendentalnym podmiotem, wprawdzie pozbawionym własnej treści, ale za to uniwersalnym. 
Descartes R., Discours de la Méthode. Texte et Commentaire par Étienne Gilson, Paris 1987.

Dupré L., Passage to modernity. An Essay in the hermeneutics of Nature and Culture, Yale University 1993.

Gierczyński Z., Wstęp, [w:] M. de Montaigne, Próby, tłum. T. Boy-Żeleński, Warszawa 1985.

Gilson É., Jedność doświadczenia filozoficznego, tłum. Z. Wrzeszcz, Warszawa 2001.

Hartle A., Montaigne and skepticism, [w:] U. Langer, The Cambridge Companion to Montaigne, New York 2005.

Hume D., Badania dotyczace rozumu ludzkiego, tłum. J. Łukasiewicz, K. Twardowski, Warszawa 1977.

Leszczyński D., Między watpieniem a wiara. Próba charakterystyki renesansowego sceptycyzmu, „Studia Philosopica Wratislaviensis” 1 (2006).

Limbrick E., Montaigne et Saint Augustin, „Bibliotheque d'Humanisme et Renaissance” 34 (1972).

Montaigne M. de, Próby, tłum. T. Boy-Żeleński, t. 1-3, Warszawa 1985.

Paganini G., Michel de Montaigne, [w:] Skepticism: from antiquity to the present, D.E. Machuca, B. Reed (eds.), New York 2018.

Pascal B., Myśli, tłum. T. Boy-Żeleński, Warszawa 1983.

Penelhum T., God and Skepticism: A Study in Skepticism and Fideism, Dordrecht 1983.

Popkin R.H., The History of Scepticism from Erasmus to Spinoza, Berkeley 1979.

Popkin R.H., The Sceptical Crisis and the Rise of Modern Philosophy, „The Review of Metaphysics" 7 (1953).

Popkin R.H., Skepticism and the Counter-Reformation in France, „Archiv für Reformationsgeschichte - Archive for Reformation History" 51 (1960).

Sekstus Empiryk, Zarysy pirrońskie, tłum. A. Krokiewicz, Warszawa 1998.

Stróżewski W., Taranczewski P., Wyktady lubelskie o estetyce, Kraków 2016.

Taylor Ch., Źródła podmiotowości. Narodziny tożsamości nowoczesnej, tłum. M. Rychter et al., Warszawa 2001.

Vázquez M.B., The Skepticism of Michel de Montaigne, New York 2015.

Wild M., Die antropologische Differenz. Der Geist der Tiere in der frühen Neuzeit bei Montaigne, Decartes und Hume, Berlin-New York 2006.

Ziemińska R., Historia sceptycyzmu. W poszukiwaniu spójności, Toruń 2013.

Ziemińska R., Michel de Montaigne jako sceptyk renesansowy, [w:] Z dziejów filozoficznej refleksji nad człowiekiem. Ksiega Pamiatkowa ku czci Profesora Jana Czerkawskiego (1939-2007), P. Gutowski, P. Gut (red.), Lublin 2007. 